\title{
Fixation of Cancellous Bone and Physeal Fractures in Dogs and Cats. A Comparison of the Use of Self-reinforced Biodegradable Devices to the Use of Metallic Devices and External Fixations
}

\author{
By Per B. Axelson \\ Department of Surgery, College of Veterinary Medicine and \\ Small Animal Clinic MEVET, Helsinki, Finland.
}

\begin{abstract}
Axelson, P. B.: Fixation of cancellous bone and physeal fractures in dogs and cats. A comparison of the use of self-reinforced biodegradable devices to the use of metallic devices and external fixations. Acta vet. scand. 1989, 30, 259-265. - The use of self-reinforced biodegradable devices made of polyglycolide in the cancellous bone and physeal fractures of dogs and cats was compared to the use of metallic devices and external fixations on similar fractures. The series consisted of 64 dogs and 22 cats divided into 6 comparable groups. The patients in the 2 groups fixed with biodegradable devices started to use their operated limbs earlier than in the other groups. The same 2 groups also healed clinically (showed no lameness) earlier than the other groups. Radiographically there was no statistical difference between the 6 groups.

On the basis of this study it may be concluded that the fixation with self-reinforced biodegradable devices is as suitable for the fixation of cancellous bone and physeal fractures of dogs and cats as the fixation with metallic devices or external fixation. This biodegradable technique has additional benefits allowing the patients to feel less pain in their operated limbs and making secondary operations to remove the devices unnecessary.
\end{abstract}

fracture fixation; resorbable devices; traumatology.

\section{Introduction}

Despite the great development of the external and internal techniques to fix fractures in small animals during the last 4 decades, there are still some disadvantages of these methods.

The application of external devices will sometimes cause secondary problems with the skin and circulatory disturbances ( $\mathrm{Orm}$ rod 1966). Joint stiffness, loosening of the external splint and infections can appear as secondary complications of the external fixation (Björck 1952, Carter 1966, Dingwall 1974).

The secondary operation often needed to remove the metallic devices is a great inconvenience when using internal fixation of fractures (Brinker et al. 1984, Arnoczky 1985). Complications of the internal metallic fracture fixations are osteoporosis, due to too rigid fixation (Tonino et al. 1976, Akeson et al. 1976, Paavolainen et al. 1987), the loosening of the devices before the fracture has healed, and infections around them (Cochran 1969, Uthoff \& Dubuc 1971, Slätis et al. 1978).

The use of most metallic implants to fix physeal fractures in dogs will often cause premature closure of the growth plate and 
thus a retarding effect on the growth of the bone (Campbell et al. 1959).

A team led by Rokkanen and Törmälä developed a self-reinforced biodegradable device for fracture fixation made of polyglycolide (Törmälä et al. 1984 and 1986). The biodegradable devices were rod-shaped (biorods) and produced in different sizes (Biofix TM). Their biochemical and physical properties as well as experimental studies indicated that they were suitable for fixations of cancellous bone (Vainionpää 1986 and Vainionpää et al. 1987) and physeal fractures (Mäkelä et al. 1987). The first clinical study with these biorods was made on 44 fractures of human ankles, type Weber A and B (Rokkanen et al. 1985).

The first clinical veterinary use of these biorods was described as case reports of a dog and a cat (Axelson et al. 1988a). Cancellous bone fractures (Axelson et al. 1988b) and physeal fractures (Axelson et al. 1988c) of dogs and cats were fixed using the same technique.

This study aims to compare the healing of cancellous bone fractures and physeal fractures fixed with self-reinforced biodegradable devices made of PGA (Biofix TM) to the healing of similar fractures fixed with external fixation and with traditional metallic devices.

\section{Materials and methods}

The series in this study was divided into 2 sections, the cancellous bone fractures, section $C=43$ cases ( 40 dogs and 3 cats) and physeal fractures, section $P=43$ cases (24 dogs and 19 cats). these 2 sections were both divided into 3 groups, fractures internally fixed with biodegradable devices (b, 27 cases), fractures internally fixed with metallic devices (i, 34 cases) and fractures fixed with external devices (e, 25 cases). The average age in section $C$ was $7.7(5.3-8.5)$ months and in section P 6,3 (6.1-6.7) months. The average weight of the patients in section $\mathrm{C}$ was $8.1(5.4-10.3) \mathrm{kg}$ and in section $\mathrm{P} 7.4$ (5.5-8.4) kg (Table 1).

Table 1. The patients in each group. Average age is given in months and average weight in $\mathrm{kg}$.

\begin{tabular}{lrrrr}
\hline Group & Dogs & Cats & Av-Age & Av-Weight \\
\hline $\mathrm{Cb}$ & 10 & 2 & 5.3 & 5.4 \\
$\mathrm{Ci}$ & 18 & 1 & 7.5 & 8.5 \\
$\mathrm{Ce}$ & 12 & 0 & 8.5 & 10.3 \\
$\mathrm{~Pb}$ & 9 & 6 & 6.2 & 8.4 \\
$\mathrm{Pi}$ & 10 & 5 & 6.1 & 8.1 \\
$\mathrm{Pe}$ & 5 & 8 & 6.7 & 5.7 \\
\hline
\end{tabular}

According to the Salter classification of physeal fractures in section P, 22 cases were of type I, 13 cases of type II, 1 case of type III and 7 cases of traction type. All cases fixed with biodegradable devices (group $\mathrm{Cb}$ and $\mathrm{Pb}$ ) were published earlier in 2 studies of the method of fracture fixation with biodegradable implants in small animals (Axelson et al. $1988 \mathrm{~b}, \mathrm{c})$. The cases in the other groups $(\mathrm{Ci}, \mathrm{Ce}, \mathrm{Pi}$ and $\mathrm{Pe}$ ) were collected from the Small Animal Clinic of the College of Veterinary medicine in Uppsala, Sweden. The comparable factors of the cases in these groups consisted of facts from their clinical records and the evaluations of their radiographs. The following aspects were listed and statistically compared:

1. When did the patient start to use the operated limb?

2. When did the swelling of the injured region disappear?

3. When did the patient start to use the injured limb without lameness?

4. Was the reduction good, acceptable or poor?

5. How soon after the accident was the fracture fixed?

6. Did any malposition of the fragments occur? 
7. Did the radiographic density decrease in the fracture line?

8. Did callus formation appear on the radiographs?

9. When did the fracture line disappear on the radiographs (in the C-groups) or; Did the fixed physeal plate show premature closure (in the P-groups)?

10. Could any malformation of the fragments be seen?

11. Could any changes of degenerative joint disease (DJD) be seen in the nearby joints?

Statistical evaluations were made on clinical and radiographical observations. The groups $\mathrm{Cb}+\mathrm{Pb}$ were tested against $\mathrm{Ci}+\mathrm{Pi}+\mathrm{Ce}+$ $\mathrm{Pe}$, and separately $\mathrm{Cb}$ against $\mathrm{Ci}+\mathrm{Ce}$ and $\mathrm{Pb}$ against $\mathrm{Pi}+\mathrm{Pe}$. The Chi-square test was used as primary statistical method, which was useful as a final test when the variables had only two alternatives ( $p<0.01$ was considered significant). Additionally, the test of Wilcoxon was used when the classification of the groups was ordered and Fisher's exact test when the question contained the direction of the hypothesis (onetailed interpretation), e.g. how much sooner a change took place in one group compared to another.

\section{Characteristics of the series}

The cases in the groups $\mathrm{Cb}$ and $\mathrm{Pb}$ consisted of ordinary patients with simple cancellous bone or physeal fractures from the Department of Surgery at the College of Veterinary Medicine and Small Animal Clinic Mevet both in Helsinki, Finland. The biodegradable fracture fixation technique was used in all suitable fractures in these clinics during the autumn 1986 and all the year 1987. The cases in the 4 other groups $(\mathrm{Ci}, \mathrm{Ce}, \mathrm{Pi}$ and $\mathrm{Pe}$ ) consisted of retrospectively collected radiographs and clinical records of ordinary patients during the years 1982-1987 in the Department of Clinical Radiology and the Department of Surgery of the College of Veterinary Medicine, Swedish University of Agricultural Sciences, Uppsala, Sweden. All patients accepted into these series met the same requirements. They have simple cancellous bone fractures (section C) or physeal fractures (section P) without infections or other complications. The surgical standard in these clinics is at the same level. The evaluation of the clinical lameness was made with the same scale in all groups (scale $0-4$ ). The estimation of the clinical swelling of the operated area was made from the radiographs. All radiographs were evaluated by the same person.

The distribution of dogs and cats in the different groups was similar within the sections. The groups with cancellous bone fractures (section C) had only a few cats while $45 \%$ of the patients in the groups of physeal fractures (section $\mathrm{P}$ ) were cats $(\mathrm{Pb} 40 \%, \mathrm{Pi}$ $33.3 \%$, Pe $61.5 \%$ ). The average ages and weights of the cases in the different groups were so close to each other that these factors could not influence the statistical results. The differences of the anatomical site of the fractures were similar in 5 groups, $6.7 \%$ 16.7 in the foreleg. Only the group $\mathrm{Ci}$ had $53.0 \%$ of the cancellous bone fractures in the foreleg. This fact could have a small but not decisive effect on the statistical result because this group represented only $22 \%$ of the whole material. The distribution of the Salter classifications of the physeal fractures within the groups of section $\mathbf{P}$ had no mentionable differences.

Due to these facts the groups were considered comparable.

\section{Results}

Clinical results

All cases fixed with biodegradable devices 
(group $\mathrm{Cb}$ and $\mathrm{Pb}$ ) started to use their operated limbs within the first post-operative week while $59 \%$ of the cases fixed with metallic devices (group $\mathrm{Ci}$ and $\mathrm{Pi}$ ) did the same. The percentage of the cases walking without lameness with the 6th postoperative week in the group $\mathrm{Cb}$ and $\mathrm{Pb}$ was 96 and in the groups $\mathrm{Ci}, \mathrm{Ce}, \mathrm{Pi}$ and $\mathrm{Pe} 50$. The local swelling or edema of the fixed fractures was very similar in all groups.

\section{Radiographical results}

The success of the reductions of the fragments in the different techniques was the same. $88 \%$ of the cases in the groups $\mathrm{Cb}$ and $\mathrm{Pb}$ showed no malalignment of the fixed fragments while the corresponding percentage in the groups $\mathrm{Ci}, \mathrm{Ce}, \mathrm{Pi}$ and $\mathrm{Pe}$ was 91 . The radiographical closure of the fixed fracture line could be seen in $75 \%$ of the biodegradable groups and in $45 \%$ of the other groups within 6 weeks. No definite premature closure of the fixed growth plate was estimated from the radiographs in $87 \%$ of the cases operated with biodegradable devices while the percentage of the cases fixed with other methods was 75 . The percentage of other complications such as malformation, infections or degenerative joint disease was very small and similar in all groups.

\section{Statistical results}

According to the statistical evaluation there were only 2 differences between the groups fixed with biodegradable devices $(\mathrm{Cb}$ and $\mathrm{Pb}$ ) and the other groups ( $\mathrm{Ci}, \mathrm{Ce}, \mathrm{Pi}$ and $\mathrm{Pe}$ ). The patients with biodegradable fixation showed earlier use of their operated limbs compared to the patients fixed with other techniques (aspect 1). With the Fisher's exact test the value $p=0.00009$ was obtained. Another difference in the study was indicated by the fact that the patients in the groups $\mathrm{Cb}$ and $\mathrm{Pb}$ could walk earlier with- out lameness than the patients in the other groups (aspect 3). The difference is seen in a divided analysis of the section $\mathrm{C}$ and $\mathrm{P}$ (Wilcoxon's rank test $\mathrm{p}<0.0001$ ). In no other aspects (aspect 2 and 4-11) was there any statistical difference between the groups of the fixations with biodegradable devices $(\mathrm{Cb}$ and $\mathrm{Pb})$ and the other groups $(\mathrm{Ci}, \mathrm{Ce}, \mathrm{Pi}$ and $\mathrm{Pe})$. Even the radiographical closure of the fracture line showed no distinct difference.

\section{Discussion}

The statistical results of this study showed evidently that the patients operated with the fixation technique of biodegradable devices used their operated legs earlier than the patients in the other groups. That could be due to the fact that the bending strength and the elastic modulus (Young's modulus) of the biorod corresponded better to the properties of the bone than the bending strength and elastic modulus of the metallic plate and screw (Vainionpää et al. 1987). In comparison with the pinning technique this method is more gentle to the bone tissue because the biorods are inserted into a drilled channel while the pins forced into the bone tissue cause damage to the structure of the bone.

The equal swelling of the operated areas showed that there were no differences of the damage to the soft tissue in the operated areas between these fixation methods and the biorod caused no more reaction or inflammation of the surrounding soft tissue than the metallic devices did.

The earlier clinical healing (= no lameness) of the fracture when using biorods could possibly be explained by the ability of the biodegrading implant to shift earlier the normal stress of the bone from the implant back to the tissue thus causing earlier regeneration of the bone. This observation has not been published earlier but could be of great 
importance to the treatment of fractures. Therefore, this needs further research. The external fixation will cause soft tissue and joint damage, which will prolong the clinical healing of the fracture.

As there were no statistical differences in the exactness of the reduction it cannot be more difficult to use biodegradable devices instead of metallic devices or applying the technique of external fixation.

No time factor affected the healing results because there were no statistical differences of the time periods between the accident and the operation.

The biodegradable implants used in this study (Biofix TM) had sufficient fixating properties compared to metallic devices and external fixation devices not to cause any differences in the firmness of the fracture fixations or in the callus formations around the fractures.

Although clinical healing appeared earlier with the method of biodegradable devices than the conventional techniques there was no difference in radiographic healing (= closure of the fracture line) between these methods. This fact shows that the fracture line does not have to be calcified to be stable and not sore (compare with the growth plate).

The use of biodegradable devices did not differ statistically from the other techniques in their effect on the physeal plate in growing dogs and cats. They all caused equal premature closure of the growth plate contrary to a preclinic study of four cats with experimental physeal fractures fixed with the same device (Axelson et al. 1988c). The biorods used in this study were obviously too thick to be broken by the growth power of the bone within 3 weeks. Moreover the drill hole through the growth line was big enough to destroy more than $3 \%$ of the area of the physeal plate, which alone would cause premature closure of the growth plate (Mäkelä et al. 1987).
When using biodegradable devices no secondary operation to remove the implants is needed, which seems to be the most striking advantage of this technique. Unfortunately, the patients in the groups fixed with metallic devices were collected retrospectively and many of them had moved from the area and could not be reached. Therefore, the accurate details concerning the removals of the implants could not be dealt with in this study. The modern manuals of orthopedics advice most metallic devices used in cancellous bone fractures and all metallic devices used in physeal fractures to be removed.

\section{Acknowledgement}

Sincere thanks are extended to Professor Nils-Erik Ahlberg, Department of Clinical Radiology of the College of Veterinary Medicine, Swedish University of Agricultural Sciences, Uppsala, Sweden for his valuable suggestions and discussions and for supplying the cases fixed with metallic devices and external fixation. The author also wishes to express his gratitude to Docent Matti Kataja for his invaluable help with the statistical evaluation in this study.

\section{References}

Arnoczky SP: Muscosceletal System. In: Textbook of Small Animal Surgery. Slatter DH (ed.). WB Saunders Co. Philadelphia, Section XVIII 1985, 1926-2286.

Axelson P, Räihä J, Mero M, Vainionpää S, Törmälä $S$, Rokkanen $P$ : The use of biodegradable implant in fracture fixation. A literature review and a report of two clinical cases. J. Small Anim. Pract. 1988a, 29, 249-255.

Axelson PB, Räiha J, Sittnikow K, Skutnabb K, Mero M, Vainionpää S, Törmälä S, Rokkanen $P$ : The use of biodegradable implants in fracture fixation of small animal cancellous bone fractures. Acta vet. scand. 1988b, 29, 469-476. Axelson P, Mäkelä A, Vainionpää S, Mero M, Rokkanen P: Biodegradable implants in the fixation of physeal fractures in cats and dogs. Acta vet. scand. 1988c, 29, 477-484. 
Björck G: Transfixationsgipsning vid behandling av frakturer hos mindre husdjur. (A transfixation plaster cast in the treatment of small animals). Nord. Vet.-Med. 1952, 4, 205-242.

Brinker WO, Hohn RB, Prieur WD: Manual of internal Fixation in Small Animals. SpringerVerlag, Berlin-Heidelberg-New York-Tokyo 1984.

Campbell JR, Grisolia A, Zanconato G: The effects produced in the cartilaginous epiphyseal plate of immature dogs by experimental surgical traumata. J. Bone Joint Surg. 1959, 41, 1221-1240.

Carter HE: Limb fractures in the dog and cat. Postoperative therapy and management. J. Small Anim. Pract. 1966, 7, 147-154.

Cochran GVB: Effects of internal fixation plates on mechanical deformation of bone. Surg. Forum 1969, 20, 469-471.

Dingwall JS: Fractures. In: Canine Surgery. 2nd Archibald ed. Amer. Vet. Publ. Santa Barbara, California 1974, p. 949-996.

Mäkelä EA, Vainionpää S, Vihtonen K, Mero M, Laiho J, Törmälä $P$, Rokkanen P: The effect of a penetrating biodegradable implant on the epiphyseal plate: An experimental study on growing rabbits with special regard to polyglactin 910. J. Pediatric Orthop. 1987, 7, 415 -420 .

Ormrod AN: Limb fractures in the dog and cat. Fractures of the forelimb. J. Small Anim. Pract. 1966, 7, 155-162.

Paavolainen P, Karaharju E, Slätis P, Ahonen $J$, Holmström $T$ : Effect of rigid plate fixation on structure and mineral content of cortical bone. Clin. Orthop. 1987, 136, 287-293.

Rokkanen $P$, Vainionpää $S$, Vihtonen $K$, Törmälä $P$, Laiho L, Kilpikari J, Tamminmäki $M$ : Biodegradable implants in fracture fixation: Early results of treatment of fractures of the ankle. Lancet 1985, 1422-1424.

Slätis $P$, Karaharju E, Holmström T, Ahonen J, Paavolainen $P$ : Structural changes in intact bone after application of rigid plates with and without compression. J. Bone Joint Surg. 1978, 60-A, 516-522.

Tonino AJ, Davidson DL, Klopper PJ, Linclau $L-A$ : Protection from stress in bone and its effects. J. Bone Joint Surg. 1976, 58-B, 107113.

Törmälä P, Rokkanen P, Kilpikari J, Pätiälä H, Vainionpää S, Vihtonen K, Mero M: Apparails chirurgicaux. Belgian Patent 1984, 900513.

Törmälä P, Laiho J, Helevirta P, Rokkanen P, Vainionpää $S$, Böstman $O$, Kilpikari J: "Resorbable surgical devices". Vth international Conference PIMS, Polymeres in Medicine and Surgery, Leeuwenhorst Congress Center, Holland, 10.-12. Sept. 1986, 16/1-16/6.

Uthoff $H K$, Dubuc FL: Bone structure changes in the dog under rigid internal fixation. Clin. Orthop. 1971, 81, 167-170.

Vainionpää $S$ : Biodegradation of polyglycolic acid in bone tissue: An experimental study on rabbits. Arch. Orthop. Trauma Surg. 1986, 104, 333-338.

Vainionpää S, Kilpikari J, Laiho J, Helevirta $P$, Rokkanen $P$, Törmälä $P$ : Strength and strength retention in vitro, of absorbable, selfreinforced polyglycolide (PGA) rods for fracture fixation. Biomaterials 1987, 8, 46-48.

Akeson WH, Woo SL-Y, Rutherford l, Coutts $R D$, Consalves $M$, Amiel $D$ : The effects of rigidity of internal fixation plates on long bone remodelling. Acta Orthop. Scand. 1976, 47, 241-249.

\section{Sammanfattning}

Fixation av spongiösa ben och fyseala frakturer hos hund och katt. En jämförelse av resorberbara implantats användning gentemot användning av metallimplantat och external fixation.

Användningen av resorberbara implantat gjorda av polyglykolsyra jämfördes med användningen av implantat gjorda av metall samt användningen av external fixation på likvärdiga spongiösa ben och fyseala frakturer hos hund och katt. De primära statistiska värderingarna gjordes med Chi-square test $(\mathrm{p}<0.01$ ansågs relevanta) och avvikande resultat bestyrktes med tester av Wilcoxon och Fisher. Serierna bestod af 64 hundar och 22 katter indelade i 6 jämförbara grupper.

Patienterna i de 2 grupperna som berörde fixationer med resorberbara resultat använde sina opererade ben tidigare än patienterna $\mathrm{i}$ de övriga grupperna. Patienterna i de 2 först nämnda grup- 
perna var även tidigare ohalta än de övriga. Radiografiskt kunde ingen statistisk skillnad påvisas mellan de 6 grupperna.

Resultatet av denna studie var att fixationer av spongiösa ben och fyseala frakturer hos hund och katt med resorberbara implantat är lika användbara som fixationer med metallimplantat och ex- ternala fixationer. De största fördelarna med de resorberbara implantaten är att patienterna känner mindre smärta $\mathrm{i}$ det opererade benet och att fixations-implantaten icke behöver avlägsnas i ett extra kirurgiskt ingrepp, som skulle betyda ytterligare risker och smärta för patienten och extra kostnader för dess ägare.

(Accepted August 30, 1988).

Reprints may be requested from: Per B. Axelson, Small Animal Clinic MEVET, Ulfsbyvägen 25, SF-00350 Helsingfors, Finland. 
